\title{
Old Norse Nicknames: Origins and Terminology
}

\author{
Paul R. Peterson
}

Department of Humanities, University of Minnesota, Morris, MN, USA

Nicknames, which occur in all cultures and time periods, play a unique role in highlighting identity. The pool of first names has always been relatively limited, thus most people were identified by their nicknames, especially before surnames became commonplace. The quantity of nicknames in Old Norse literature is large, and recurring nicknames provide a tool for understanding narrative transmission, cultural history, and etymology. Medieval explanations for giving nicknames are suspect, but they provide a glimpse into the possible reasons for so many of them coming down to us. An overview on nickname terminology is provided, as well as literary examples showing the fluidity of medieval terminology in nickname narrative explanations. The overall approach is therefore to explore the ways in which nicknames are described in the literature and how this information aids in understanding medieval Norse society and culture through its naming customs.

KEYWORDS nicknames, bynames, anthroponymics, cognomina, Old Norse, terminology, medieval names

\section{Introduction}

Nicknames exist everywhere and can be found in all cultures at all times. From Icelandic farmers to modern politicians, almost everybody has had a nickname - sometimes obscene, and frequently demeaning. Nicknames, which are sometimes better known than people's real names, are an expression of wit and meant to brand an individual. The function of nicknames in the Middle Ages is peculiar, when kings could be called such derogatory names as Charles the Fat (Carolus Pinguis, 839-888), Charles the Bald (Carolus Caluus, 823-877), Louis the Stammerer (Ludovicus Balbus, 846-879), Æthelræd Unrced 'ill-advised' (died гог6), and so on. It is precisely because nicknames are so frequently insulting and seem to conflict with codes of honor in medieval society 
that their original humor and cutting wit still resonate with us. They often look like jokes but pose hard questions to scholars. Why were aggressive men, so touchy and prepared to kill for an incautious allusion, ready to tolerate public humiliation in the form of nicknames? How did Icelandic nicknames, preserved in the famous sagas, contribute to the artistic texture of the narrative? When kings could be called demeaning names like Sigurðr Sow, Eysteinn Fart, or Hákon the Crazy, one can only wonder whether or not such nicknames would have actually been uttered in their presence.

Nicknames were always transparent, otherwise no one needed them, but today many of them are among the most opaque words from an etymological point of view. This is so despite the fact that, unlike its continental sister languages, Icelandic has changed so little, that "Old" Icelandic remains - except for phonetic and lexicological differences - the mother tongue of twenty-first-century Iceland. Since the continuity of literary and popular tradition in Iceland - including the medium of the language - is stronger than anywhere else in Europe, nicknames in the Icelandic sagas provide a bridge between past and present culture. The corpus of Old Icelandic literature is large, but the language is stylized, and the frequent use of nicknames provides a way to break through the formulaic nature of the texts. The rich narrative currency of the sagas stemmed from an oral storytelling tradition, with frequent interplay between oral and written sources, and nicknames were frequently used as "seeds" from which a story could be cultivated.

The number and variety of Old Norse nicknames is richer than any other medieval Germanic society. Janzén $(1947,242)$ notes the high volume of Old Norse bynames: "Binamnen kom i Norden i bruk i en omfattning som är ojämförligt större än i andra delar av den germanska världen (Bynames came into use in the Nordic world to an extent which is incomparably larger than in other parts of the Germanic world)." In his seminal work The Saga Mind, Steblin-Kamenskij points to the reason for the large quantity of names in the sagas:

The abundance of names in family sagas is also due to the inability to portray thehuman personality by itself, outside its relationships with other people, outside a feud ... but there is still another reason for the abundance of names in the familysagas - proper names were not then what they seem to us now. (I973, 65-6)

What seems, at least to us, excessive name-dropping in the sagas is no accident, because the medieval Icelandic mind conceived of individuals primarily in relation to others, in the same way that character traits were considered hereditary. Regarding the prominence of names in the sagas, Steblin-Kamenskij later noted: "The family sagas mention in all more than seven thousand persons; single sagas mention hundreds, long sagas many hundreds" (I973, 65). Many of these over seven thousand names overlap, of course (there are fifteen men named Porkell, for example, in Njáls saga). Considering that a large number of individuals in the sagas also have nicknames, which are more diverse in character than the stock of first names, it is not difficult to grasp that there is an overwhelming quantity of onomastic data in these sources. 
Certain nicknames may even have provided the basis of an entire saga character's biography, and were used as a narrative tool in oral tradition. Nicknames in the sagas are important for providing motivation for actions and behavior, imagined by the saga compiler or otherwise. We cannot always grasp the motivations for the dubbing of nicknames, but occasionally saga narratives comment on nicknames and provide their own explanations of them. Most nicknames mentioned in the sagas go unexplained, but the narratives explaining a nickname's origin are of an anecdotal type - that is, a brief narrative comment on a particular feature, event, or other basis from which an individual received a nickname. Although most passages describing nicknames are not particularly rich examples of narrative, their mention can enable scholars to decipher some of the narrative "seeds" from which sagas were created.

Bynames, including titles, nicknames, patronymics, and matronymics, among others, have their share of reference works. The standard comprehensive work on Old Norse - Icelandic bynames is Lind's (I920/I) dictionary. Most of the bynames are provided with a gloss of likely or possible meanings, as well as literary citations of where the various individuals bearing them are found. One notable problem with the dictionary is its age, because many of the textual editions cited are outdated. Despite this, Lind's collection is the most complete available. An updated edition is lacking, and scholarship could benefit greatly from a second edition, ideally with updated etymologies and literary references (and in English or German, to reach a wider readership). Lind's dictionary, however, was not without predecessors. A substantial collection of Norse bynames was published in Rygh (I87I), which Finnur Jónsson (1907) later divided into categories by type. For a fuller treatment of the scholarly literature on the topic of Old Norse nicknames, I refer the reader to my dissertation (Peterson 20I 5, 7-I 5 ).

Several issues in Old Norse nickname research are addressed here in order to show some of the many directions in which their study can go. First, a cultural and literary background in the motivations for giving nicknames is provided in order to explain why so many individuals in Norse society were given nicknames in the first place. Second, an overview of the terminology used to describe Old Norse nicknames is provided in order to show how imperfect the application of such terms is. Lastly, the terminology used to describe Old Norse nicknames is shown with examples of narrative explanations from Old Norse literature for the purpose of highlighting the problematic application of medieval terminology. The overall approach is to provide a suitable onomastic and terminological framework for which to describe Old Norse nicknames in their immediate cultural context.

\section{Medieval Thoughts on Nicknames}

Rarely are the naming customs of any past society, let alone their practice of nicknaming, stated explicitly by its members. Therefore, the few examples which turn up are precious for understanding cultural practices and the motivations behind them. A single passage in Old Icelandic literature reveals how medieval 
Icelanders may have perceived the significance of nicknames. In Porsteins saga buita, Porsteinn's foster son Brodd-Helgi ('Spike-') is given a nickname to commemorate his trickery for attaching a spike to a bull's forehead to level a fight with a larger bull. His nickname is then explained in relation to the preChristian custom of giving nicknames:

Fekk hann af pessu pat viðrnefni, at hann var kallaðr Brodd-Helgi, en pá pótti monnum pat miklu heillavænligra at hafa tvau nợn. Var pat pá átrúnaðr manna, at peir menn myndi lengr lifa, sem tvau nofn hefði (He received the nickname from this event that he was called Brodd-Helgi, and back then it seemed to people greatly promising to have two names. At that time it was people's belief that the people who had two names would live longer). (Jón Jóhannesson I950, I9)

Though suspect, this passage illuminates what would make sense as the central motivation for giving and receiving nicknames.

A similar mention of Old Norse naming practice occurs in an isolated short paragraph from the late-seventeenth-century $A M 28 \mathrm{I}$ fol. (IO3r), ${ }^{2}$ where the compounding of names of heathen gods to first names is described in theophoric constructions such as Pórr (Thor) and Grimr (<the adjective grimr 'fierce')> Porgrimr:

Pad er fródra manna søgn ad pad være sidur i firndinne, ad Draga af nøfnum Gudanna nøfn sona sinna, so sem af Pórs nafne Porolf, edur Porstein edur Porgrim, eda sa er Oddur hiet, first skillde heita af hans nafne Póroddur sem Pormódur qvad vm Snorra goda og Odd son hans er kalladi Porodd edur Porbergur, Porálfur, Porleifur, Porgeir. Enn eru fleire nofn Dreiginn af peim gudum og Ásum, po ad af Pór sie flest, menn høfdu ba og mioc ij nofn, potti pad lijklegt til langlijfis og heilla, pott nockrir fyrimællti peim vid Gudinn, pa mundi ba ecki skada ef peir ætti annad nafn (It is a saying among wise men that this was the custom in ancient times, to draw their sons' names from the names of the gods, such as Pórólfr from Pórr's name, or Porsteinn or Porgrímr, or the one who was first called Oddr decided to be called by his name Póroddr, just as Pormóðr said about Snorri goði ('chieftain') and his son Oddr whom he called Póroddr or Porbergr, Pórálfr, Porleifr, and Porgeirr. Yet there are more names drawn from the gods and the Æsir, although Pórr is the most used, at that time people often had two names, it seemed promising to a long life and well-being, although some people would swear themselves to the gods, then nothing would harm them if they had a second name). (Eiríkur Jónsson and Finnur Jónsson I892-1896, 503-4) ) $^{3}$

Although this passage is explaining the theophoric compounding of first names, it echoes the logic used to explain Brodd-Helgi's nickname in Jón Jóhannesson (I950), that the possession of a nickname - or in this case a name with two components (one of mythological origin) - was considered a promising (heillavenligr) feature and promoted a long, healthy life. This passage also contains a heavy overlay of medieval folk etymology. The occurrence of the idea that having two names is lucky might account to a limited degree for reality, even though there is not enough evidence to accept this as historically verifiable.

Roughly the same idea regarding the importance of having two (or more) names was also found in medieval England, where having more than one name 
- especially an official name - signified high rank. In a discussion of surnames in his first edition, Camden provides reasoning for the adoption of second names in medieval England:

So it feemed a disgrace for a Gentleman to have but one fingle name, as the meaner forte and baftards had. For the daughter and heire of Fitz-Hamon a great Lord, as Robert of Gloucefter in the Librarie of the induftrious Antiquary maifter Iohn Stowe writeth, when King Henry the firft would have married hir to his bafe fonne Robert, fhe firft refufing anfwered;

It were to me a great Shame,

To have a Lord without'n his twa name.

whereupon the king his father gave him the name of Fitz-Roy, who after was earle of Gloucefter, and the onely Worthy of his age. (Camden I605, 94-5)

Regarding the cutting distich in reply to the marriage proposal by King Henry I on behalf of his illegitimate son Robert, it is presumably by the Anglo-Norman noblewoman and Countess of Gloucester Mabel FitzRobert (I090-I I57). As a result of her initial refusal to marry Robert, King Henry I surnamed his son Fitzroy (= 'son of the king'; fitz < Norman filz < Latin filius 'son'), which looks like a regular patronymic but may also have served as a kind of title. In any case, it seems that already in twelfth-century England, if the account given here is reliable, the adoption of a second name could be beneficial to one's societal status.

\section{Terminology}

The vocabulary that surrounds the classification of nicknames is enormous and varies from language to language. Therefore, defining clear-cut examples within such classifications is challenging. In English, the all-inclusive term nickname causes confusion where it is often used by both specialists and non-specialists to describe hypocoristic (or pet) names that do not accurately represent nicknames but rather one type of byname derived from a regular first name (e.g. Johnny, Bob, Teddy, etc.). The "test" for what qualifies as a nickname, strictly speaking, is that it can stand with a regular name, usually in apposition (Robert Bob or John Johnny, for example, are not natural fits). Like hypocoristic names, however, a nickname can also stand alone in place of a regular name; thus, The Babe is understood to mean George Herman "Babe" Ruth. Other terms used for nicknames in English like moniker, sobriquet, the antiquated form to-name (cf. German Zuname 'surname'), and byname all pose their own problems: moniker is a recent coinage, sobriquet is not widely understood by English speakers, to-name is a dead form, and byname describes secondary names of several sorts, including nicknames but also surnames, titles, and patronymics and matronymics.

The same issue of loose terminology is ubiquitous across linguistic boundaries, in part due to the conflation of the separate traditions of giving nicknames and 
giving pet names derived from first names. Yet the medieval evidence, as best as I can tell, made a stronger distinction between nicknames and hypocorisms. Although pet names are not well-represented in medieval Scandinavian sources, they were more common in other Old Germanic societies. Among Old Germanic societies, one practice consisted of giving a shortened byname; that is, a diminutive, familiar pet form (such as the Norse names Óli for Óláfr, Tósti for Porsteinn, and Kalli for Karl). Many such pet names became regular first names through frequent use. The other practice consisted of adding a secondary name or agnomen as a supplement to a given name. It is primarily the latter that I am concerned with here. Although using the Latin term agnomen (pl. agnomina) is problematic, in part due to the historical developments of naming traditions and the uses of agnomina in the Roman world, it best corresponds to the meaning of nickname as it is used throughout this study. Originally the Latin term cognomen - not the modern English borrowing which does indeed mean "nickname" - would have been the most appropriate to describe nicknames, because cognomina (plural of cognomen) were originally Roman nicknames. After cognomina became inherited as supplements to clan names that identified sub-families within the clans, however, from a technical standpoint for describing nicknames the term became no longer apt.

The English word nickname implies a secondary name - or more precisely, a name which is added to an individual's first name. The term developed from ME ekename, whose first component eke- 'increase' (< Old English êaca 'addition, increase') developed into nickname ( $<$ an ekename) by metanalysis, just like newt "(a type of) salamander" was formed from an ewt. Thus, the mis-division of the syllables in an ekename was reanalyzed as nekename. It seems that nekename became wrongly associated with the verb nick 'to notch, make a shallow cut' (cf. also German necken 'to banter, tease'), as the earliest known example from I 585 suggests: "Sussuro, a priuye whisperer, or secret carrytale that slaundereth, backebiteth, and nicketh ones name" (Palmer I882, 255). The next example occurs just a few years later in a manual on poetry from 1589 , where the author (assumed to have been Puttenham) describes prosonomasia (that is, nicknaming), or more accurately in the context of poetry, paronomasia (that is, puns): "Ye haue a figure by which ye play with a couple of words or names much refembling, and becaufe the one feemes to anfwere th'other by manner of illufion, and doth, as it were, nick him, I call him the Nicknamer" (Arber I869, 2I2). The use of nick to mean "to give an insulting nickname" is also found in Camden (1605, 80): "GOODITH, Sax: Contracted from Goodwife, as we now ufe Goody: by which name king Henry the firft was nicked in contempt." Further: "The Greekes (to omit infinite others,) nicked Antiochus Epiphanes, that is, the famous, with Epimanes, that is, the furious" (I4O-I). The meanings of nick in the above examples are classic cases of folk etymology.

Returning to the North, in an attempt to avoid confusion among the numerous onomastic terms found in various languages and historical traditions, preference will be given to Old Norse terminology which best reflects the subtle nuances of terms as they come up in the discussion. Several terms in Old Norse 
are used interchangeably for nicknames. The most common one in Old Norse is viðrnefni, which signifies in the most obvious manner an "added name." There is also the Old Norse term kenningarnafn, which means something like 'an alternate name by which someone is known, a name of recognition'; the term is used interchangeably in medieval literature to mean either 'title' or 'nickname'. These terms, viðrnefni and kenningarnafn, are by their nature neutral, although kenningarnafn is often used to describe a title given as an honor.

The cognate of nickname in Old Norse is auknefni 'increased name, nickname' (cf. Swedish öknamn, Danish øgenavn, and Low German Ökelname, all with the same meaning), which can either be neutral or, in many cases, derogatory. The Old Norse term and its cognates seem to have developed from its simple meaning of an 'increased, additional name' into having a negative connotation, if only as a result of the high frequency of abusive auknefni. A near parallel term to auknefni is aukanafn, with a similar meaning 'extra title, byname' (cf. auka nafn 'to add a name' and auknefna 'to give a nickname'), which may have been coined in order to differentiate titles from nicknames. The terms auknefni and aukanafn are not entirely synonymous, but the two are related and occur by the thirteenth century when Old Norse-Icelandic literature began fully to bloom.

Auknefni, perhaps by their very nature, are so frequently negative that the authors of the standard dictionary of Old Icelandic defined the term as having two separate senses of the meaning 'eke-name, nickname': first, a defamatory name punishable by lesser outlawry; second, as a neutral nickname (Cleasby and Vigfússon 1874,34$)$. Dividing the meaning into two senses is misleading etymologically, however, because the basis for a negative connotation is contextual. Even so, this opinion is not unfounded considering that so many auknefni are indeed derogatory. There is in fact a stipulation in the Old Icelandic law code Grágás (in the Staðarhólsbók version) against giving insulting auknefni:

Ef maðr gefr manne nafn annat en hann eigi. oc varðar bat fior Baugs Garð ef hiN vill reiðaz við. sva er oc ef maðr reiðir avknefni til haðungar honom oc varðar pat fior Baugs Gard ... (If someone gives a person a different name than the one he already has, it is punishable by lesser outlawry (three years' exile) if the other one is angered by it. Thus, it is also the case if someone spreads around a nickname to degrade him, it is punishable by lesser outlawry ....). (Vilhjálmur Finsen I879, 39I-2)

This stipulation reflects the social power of "calling people names" and using nicknames as terms of abuse, and it is little shock that such a harsh penalty existed in a society where a slight against one's honor was often considered grounds for violent revenge. While the legal punishment for "name calling" was already heavy, more often than not violent revenge could be spurred on by insults exactly like these.

The verbal constructions most commonly found in Old Norse where a name often but not always including a nickname - is introduced include beita 'to be called' plus the nominative form of the name, or kalla 'to call' plus the 
accusative form of a name. It was about as common to use the verb kalla actively as it was for it to appear as a past participle, as in hann var kallaðr/hón var kolluð 'he was called/she was called.' Less common was the introduction of a name with the construction vera nefndr 'to be named.' The medio-passive nefnask 'to be named' and the phrases eiga nafn 'to possess, have a name' and hafa nafn 'to have a name' were rare. Two seldomly used verbs for the bestowing of titles are nafngipta 'to give a title' and nafnkenna 'to give a recognizable name, title.' There are five common expressions used to give bynames (nicknames or titles) at the introduction of a new name: nefna 'to name,' gefa nafn 'to give a name,' auka nafn 'to add a name,' auknefna 'to nickname,' and lengia nafn 'to lengthen a name.' Another naming term, sannnefni 'true, accurate name,' is used to verify the accuracy of a byname in terms of public opinion.

\section{Terminological Patterns in Nickname Narratives}

The use of terminology in nickname explanations varies considerably from text to text, and literary examples show ample evidence of variable definitions for different types of nicknames. To start with a famous example, the origin of the nickname of Haraldr hárfagri 'fair hair' (the epithet Fairhair is commonly used in English) is given in his eponymous saga in Heimskringla. This passage occurs when Jarl Rognvaldr gave him the new nickname after washing and cutting his hair, which for ten years prior had been uncut and uncombed, replacing his former derogatory nickname:

Pá kdluðu peir hann Harald lúfu, en síðan gaf Rognvaldr honum kenningarnafn ok kallaði hann Harald inn hárfagra, ok søgðu allir, er sá, at pat var it mesta sannnefni, pví at hann hafði hár bæði mikit ok fagrt (They called him back then Haraldr lúfa ('shock-head'), but afterwards Rognvaldr gave him a nickname and called him Haraldr hárfagri (Fairhair), and everyone said who saw him that it was the truest name of all, because he had hair both plentiful and fair). (Bjarni Aðalbjarnarson I94I, I 22)

The use of the term kenningarnafn, which was usually used to mean "title," does not seem entirely fitting - especially when hárfagri is plainly a nickname; viðrnefni 'additional name' might have been expected. One terminological variant here is followed by another naming term, sannnefni 'true, accurate name,' which affirms the appropriateness of the new nickname.

In a fragment of Guðmundar biskups saga (in AM $657 c 4^{\text {to }}$, ca. I340-1390), Guðmundr gives his friend Einarr the title klerkr 'cleric' (an occupational byname), which is described in a similar fashion as the redubbing of Haraldr hárfagri:

en hann vígði hann pá er hann var tvítugr, ok gaf honum pat kenningar nafn at hann skyldi heita Einarr klerkr, ok kvað honum pat sannnefni en eigi auknefni (and he consecrated him then when he was twenty, and gave him the title that he should be called Einarr klerkr ('cleric'), and said that to be a true name for him and not a (derogatory) nickname). ${ }^{4}$ 
This is a telling example where the terminology has been shuffled around. Even more interesting is that the kenningarnafn is said not to be an auknefni, which should only be applied to a nickname and not titles, but is instead a sannnefni. Perhaps this passage also gives some credibility to the notion that an auknefni tends to have a negative charge (despite the literal meaning 'increased name').

To differentiate between a kenningarnafn, which is either neutral as a nickname or given as an honorific title, and an auknefni, which are often derogatory (as the previous example suggests), in Fóstbroðra saga it differentiates between the two established senses of nicknames:

Helgi átti kenningarnafn ok var kallaðr hvítr, ok var honum pat eigi auknefni, pví at hann var vænn maðr ok vel hærðr, hvítr á hár (Helgi had a nickname and was called hvitr ('white'), and for him it was not a (derogatory) nickname, because he was a handsome man and had fine, white hair). (Sigurður Nordal I945, 243)

It is apparent here that a distinction was made between a kenningarnafn, which was more apt for describing a positive feature or a title (and could even be considered a sannnefni), and the often negative auknefni, echoing the description of Einarr klerkr's title.

There is one instance in Hróa páttr heimska, a short tale from Ólafs saga ins belga, where the term sannnefni is used to verify a name which is obviously derogatory. The eponymous character of the tale is named Hrói inn heimski 'the stupid, foolish,' though the entire tale disproves the accuracy of the nickname. In this passage, after meeting a beautiful young woman, he does his best not to deny the nickname in what can only be described as tongue-in-cheek modesty:

ok er hann kom at henni leit hon uit honum ok mællti. huer ertu. Ek heiti Hroi segir hann. Ertu Hroi hinn heimski segir hon. Hann suarar. ek æxtla pat nu vera ærit mikit sannefnne en att hefui ek ædri nöfnen fyrr (and when he went to her she looked at him and said: "Who are you?" "My name is Hrói," he says. "Are you Hrói inn heimski," she says. He answers: "Well, I consider that to be quite a true name, but I have had more dignified names before”). (Guðbrandr Vigfússon and Unger I 862, 77)

The use of sannnefni in this case, where the nickname does not fit and is definitely not a "true, accurate name," is an instructive example of irony, though this is perhaps the only such case of it with sannnefni in the entire literary corpus.

The term auknefni so often had a negative charge that William the Conqueror (ca. I028-I087), called William the Bastard in non-Anglo-Norman sources, denies his negative nickname and violently assaults his future wife for mentioning it. His alternative nickname (Old Norse bastarðr 'bastard') is first explained in Saga ens heilaga Eduardar in Flateyjarbók to be untrue, and instead inherited from the dukes in Normandy before him who were illegitimate offspring. This departs from other medieval sources which emphasize that he was, in fact, illegitimate. Soon after in the saga, William defends himself against his nickname as he pursues his future bride: 
hann taladi til hennar blidliga ok kalladi hana vnnastu sina. pa suarar jumfruin. er ertu vallari pinn er pu hyggr par sem ek er komin af konungligri æett mune vilia giptaz einum bastardi. Pa reiddiz hertuginn ok tok i haar henne ok felldi hana til iardar ok trad hana vndir fotum ok mællti sua. eigi er ek bastardr nema at auknefni (He spoke to her kindly and called her his sweetheart. Then the maiden answers: "Are you such a scoundrel that you think that I, someone descended from noble lineage, would want to marry a bastard?" Then the duke got angry and took her by the hair and tossed her to the ground and stomped on her under his feet and said: "I am not a bastard except by nickname”). (Guðbrandr Vigfússon and Unger I 868, 463-4)

From start to finish this scene has the making of excellent courtly drama, and - quite unexpectedly - William wins his bride, despite their first encounter ending in violence (this is probably an abbreviated "taming of the shrew" motif). With his succinct rebuttal - eigi er ek bastarðr nema at auknefni - and rather unnecessary violence, William has made his case and won a bride.

\section{Conclusion}

Old Norse nicknames provide a nearly untapped resource for investigating issues in onomastics, lexicology, etymology, narratology, and literary analysis in Old Norse scholarship. I have, naturally, discussed only a handful of the many avenues of available research on nicknames, and a more thorough investigation of this topic is necessary to discover all the features and cultural information that can be gleaned from them. A significant amount of analysis remains to solve the uses of nicknames in the literature, as well as the meaning and translation of many rare or obscure nicknames. This study however accomplishes several goals, as it highlights the cultural motivations behind giving nicknames, defines the appropriate terminology to describe nicknames, and gives a summary of the usage of the terms with examples from medieval texts. In doing so, it is hoped that this study contributes toward providing a scholarly medium in which further research on Old Norse nicknames is possible. ${ }^{5}$

\section{Notes}

I. All translations are mine.

2. From ca. $1674 / 5$.

3. This text also occurs in $A M$ II $58^{v o}$ (ca. I600-I649); a normalized version can be found in Guðbrandr Vigfússon (I 864, I 26, Anhang 2).

4. From Brot ur miðsögu Guðmundar in Biskupa sögur, Vol. I. (Jón Sigurðsson and Guðbrandur Vigfússon I 8 58, 589)
5. Since Icelandic authors do not have genuine surnames, I have alphabetized these authors by the custom used in their own country, that is, by first name followed by any other secondary name. Similarly, in the main body of the article, I have cited Icelandic authors by their full names according to the same custom.

\section{Disclosure statement}

No potential conflict of interest was reported by the author. 


\section{References}

Bjarni Aðalbjarnarson, ed. I94I. Haralds saga ins hárfagra. In Heimskringla I. Íslenzk fornrit. Vol. 26. Reykjavik: Hið íslenzka fornritafélag.

Camden, William. I605. Remaines of a Greater Work, concerning Britaine, the inhabitants thereof, their Languages, Names, Surnames, Emprefes, Wife Speeches, Poëfies, and Epitaphes. London: G. E. for Simon Waterson.

Cleasby, Richard, and Gudbrand Vigfússon. I874. An Icelandic-English Dictionary. Oxford: Oxford University Press.

Eiríkur Jónsson, and Finnur Jónsson, eds. I 892-I 896. Tillæg X Annal. In Hauksbók. København: Thiele.

Finnur Jónsson. 1907. Tilnavne i den islandske oldlitteratur. Kjøbenhavn: H.H. Thiele. (Reprinted in I908).

Guðbrandr Vigfússon, ed. I 864. Eyrbyggja saga. Leipzig: F.C.W. Vogel.

Guðbrandr Vigfússon, and C. R. Unger, eds. I862. "Hróa páttr heimska." In Flateyjarbók. Vol. 2. Christiania: Malling.

GuðbrandrVigfússon, and C. R. Unger, eds. I 868. "Saga ens heilaga Eduardar.” In Flateyjarbók. Vol. 3. Christiania: Malling.

Janzén, Assar. I947. “De fornsvenska personnamnen.” Personnavne. Nordisk kultur VII, edited by Assar Janzén, 235-268. København: Schultz.

JónJóhannesson, ed. I950. "Porsteins saga hvíta.” In Austfirðinga søgur. Íslenzk fornrit. Vol. I I. Reykjavík: Hið íslenzka fornritafélag.

Jón Sigurðsson, and Guðbrandur Vigfússon, eds. I 85 8. “Guðmundar biskups saga.” In Biskupa sögur. Vol. I. Kaupmannahöfn: Hið íslenzka bókmentafélag.

Lind, Erik Henrik. I920-2I. Norsk-isländska personbinamn från medeltiden. Uppsala: Lundequistska bokhandeln.

Palmer, Abram Smythe. I882. Folk-Etymology: A Dictionary of Verbal Corruptions or Words Perverted in Form or Meaning, by False Derivation or Mistaken Analogy. London: George Bell \& Sons.

Peterson, Paul. 20I5. Old Norse Nicknames. PhD diss., University of Minnesota, Twin Cities. Accessed April 24, 20I 8. https://www.conservancy.umn.edu/handle/I I 299/I 72669

Puttenham, George (ascribed author). I 869. The Arte of English Poesie, edited by Edward Arber. London: Murray \& Son. (Orig. pub. I 589 .)

Rygh, Karl. I87I. Norske og islandske tilnavne fra oldtiden og middelalderen. Throndhjem: G.E Petersen. Sigurður Nordal, ed. I945. Fóstbrœðra saga. In Flateyjarbók. vol. 2. Akranes: Flateyjarútgáfan.

Steblin-Kamenskij, M. I. I973. The Saga Mind, translated by Kenneth H. Ober. Odense: Odense University Press.

Vilhjálmur Finsen, ed. I 879. Grágás efter det Arnamagnæanske Haandskrift Nr. 334 fol., Staðarhólsbók. Kjøbenhavn: Gyldendal.

\section{Notes on contributor}

Paul R. Peterson gained his $\mathrm{PhD}$ in Germanic Medieval Studies from the University of Minnesota, Twin Cities in 2015. He is a postdoctoral fellow at the University of Minnesota, Morris and a faculty member at Signum University. His research concentrates on Old Norse literature and he is also interested in Germanic philology, historical linguistics, and Scandinavian studies.

Correspondence to: Paul R. Peterson, University of Minnesota, 600 E, $4^{\text {th }}$ St., Morris, MN 56267. Email: pete258I@morris.umn.edu 